\title{
县 \\ DEKONSTRUKSI KEKUASAAN DALAM KELUARGA PEKERJA MIGRAN INDONESIA DALAM PERSPEKTIF PETER M. BLAU
}

\author{
Mahardani Febrihapsari* \\ Program Studi Ilmu Administrasi Negara \\ Fakultas Ilmu Sosial dan Ilmu Politik \\ Universitas WR Supratman Surabaya \\ Wiwik Prihartanti \\ Program Studi Ilmu Administrasi Niaga \\ Fakultas Ilmu Sosial dan Ilmu Politik \\ Universitas WR Supratman Surabaya \\ Agus Rahmanto \\ Program Studi Ilmu Administrasi Negara \\ Fakultas Ilmu Sosial dan Ilmu Politik \\ Universitas WR Supratman Surabaya \\ *Email : mahardanifebrihapsari@gmail.com
}

\begin{abstract}
Abstrak
Migrasi adalah salah satu kajian kependudukan yang banyak dikaji, khususnya mengenai migrasi tenaga kerja antar negara. Perpindahan tenaga kerja yang marak belakangan ini, memberikan kontribusi yang tidak sedikit pada negara melalui remitansi. Akan tetapi di sisi lain, migrasi tenaga kerja, khususnya pekerja migran perempuan, membawa konsekuensi tersendiri dalam bentuk perubahan yang terjadi tak hanya pada tataran masyarakat, tetapi juga pada ranah keluarga. Artikel ini mencoba untuk memotret kekuasaan dalam keluarga migran setelah istri melakukan migrasi. Pendekatan yang digunakan adalah pendekatan kualitatif dengan perspektif pertukaran sosial Peter M. Blau. Hasil penelitian mengungkapkan migrasi pekerja migran perempuan merubah kekuasaan di dalam keluarga dengan adanya dekonstruksi kekuasaan dalam bentuk dominasi terhadap keputusan akhir rumah tangga. Peningkatan basis ekonomi beriringan dengan peningkatan atau bahkan penguatan posisi tawar perempuan terhadap laki-laki dalam rumah tangga. Pada tataran ini, ekonomi, menjadi determinan utama perubahan tersebut. Sementara di sisi lain, pengetahuan yang didapatkan perempuan selama diperantauan menjadi determinan minor dalam pertukaran sosial terhadap suami.
\end{abstract}

Kata Kunci : Dekonstruksi Kekuasaan, Pekerja Migran Perempuan, Posisi Tawar 


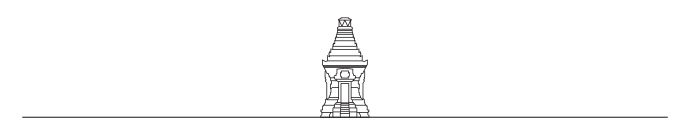

\begin{abstract}
Migration is one of population studies which has been widely reviewed, particularly labor migration between countries. A booming labor movement recently, gives no small contribution for the country through remittances. However, labor migration, women migrant workers in particular, has its own consequences in the form of changes that occur not only at community level but also at family level. This study attempts to portray power in the migrant family after the wife migrates. The approach used in this study was qualitative with the perspective of Peter M Blau Social Exchange. The results of the study reveal that migration done by women migrant workers changes the power in the family, that is power destruction in the form of domination on the final decision in the family. An increase in economy in line with an increase or even a strengthening in bargaining position of women to men in the family. In this level, Economy is the major determinant of the change. Whereas, the knowledge obtained by the women while being overseas is the minor determinant in the social exchange to husband.
\end{abstract}

Keywords : Power Deconstruction, Women Migrant Worker, Bargaining Position 


\section{PENDAHULUAN}

Migrasi merupakan salah satu kajian kependudukan yang menarik untuk dikaji, utamanya migrasi tenaga kerja antar negara. Pada tataran ini, migrasi menjadi salah satu alternatif pemecahan permasalahan ketenagakerjaan. Mantra (2013) menyebutkan dengan bekerja di luar negeri, maka pendapatan angkatan kerja bersama keluarganya dapat ditingkatkan secara substansial. Migrasi tenaga kerja antar negara atau yang lebih dikenal dengan Pekerja Migran Indonesia (PMI), memberikan kontribusi yang tidak sedikit kepada negara dalam bentuk remitansi. Bank Dunia mencatat remitansi pekerja migran pada tahun 2018 sebesar 128 triliun (www.cnnindonesia.com).

Sebagian besar Pekerja Migran Indonesia (PMI) didominasi oleh perempuan. Mengutip data Badan Pusat Statistik (BPS), perempuan mendominasi sebesar $69,1 \%$ dari jumlah tenaga kerja pada tahun 2019. Hukum migrasi Ravenstein yang menyatakan "perempuan cenderung melakukan migrasi jarak dekat", menunjukkan antagonismenya melalui derasnya arus migrasi PMI perempuan. Salah satu alasan perempuan melakukan migrasi, seperti dikemukakan oleh Wulan (2010; dalam Sulistyo \& Wahyuni, 2017) dalam kajian livelyhood strategies merupakan upaya bertahan karena ketidakmampuan kepala keluarga berperan sebagai pencari nafkah. Fakta yang diperkuat dengan hasil studi Kuntari (2015) dalam Jurnal PKS, menemukan faktor utama perempuan memutuskan untuk menjadi migran adalah kondisi kemiskinan, sementara faktor pemicu lain disebabkan karena menyempitnya lahan pertanian, kurangnya ketersediaan lapangan kerja yang sesuai dengan tingkat kemampuan, serta rendahnya upah tenaga kerja.

Derasnya arus migrasi PMI mempercepat adanya transformasi di segala sendi kehidupan, baik mewujud dalam penetrasi budaya maupun struktur mendasar, utamanya di dalam keluarga.
Ranah yang selama ini lekat dengan perempuan. Pada tataran ini, keterlibatan perempuan tak hanya mewujud dalam peningkatan perekonomian ataupun status sosial, bahkan tak jarang perempuan menggantikan peran laki-laki sebagai pencari nafkah utama. Kemiskinan memaksa perempuan untuk mengambil peran sebagai pencari nafkah, termasuk terpaksa bekerja sebagai buruh migran. Lanjutnya pekerjaan sebagai buruh migran dianggap sebagai kewajiban dan solusi untuk mengatasi belitan hutang dan kemiskinan dalam keluarga (Saptandari, 2017).

Dalam masyarakat, wilayah perempuan adalah domestik dan laki-laki publik, artinya perempuan bertugas mengurus rumah tangga, sementara laki-laki mengurus urusan publik, politik, agama dan peran sosial lainnya (Susanti, 2005). Perempuan, lanjut Susanti, bukan tidak memiliki kemampuan atau keahlian dalam bertindak di ranah publik, akan tetapi secara sosial tidak dibenarkan bagi mereka untuk melakukannya. Kondisi ini kontras dengan kondisi yang ada di masyarakat. Pada masyarakat agraris yang masih sangat kental didominasi patriarkhi, masuknya perempuan ke dalam ranah publik tak jarang menimbulkan kegoncangan dalam keluarga, dimana bentuk disrupsi yang paling kentara adalah perceraian.

Sebagai salah satu daerah penghasil PMI, Ponorogo, mencatat angka perceraian yang cukup tinggi. Pengadilan Agama (PA) Ponorogo, mencatat 1.633 kasus perceraian per September 2019, dimana $80 \%$ diantaranya berlatar belakang sebagai pekerja migran. Kasus gugatan cerai pekerja migran yang berasal dari pihak istri tergolong cukup tinggi dengan jumlah mencapai ratusan tiap bulan (www.surabayainside.com). Ketua Pengadilan Agama Ponorogo, seperti yang dilansir oleh RRI.com, menyebutkan cerai gugat yang dilayangkan oleh pekerja migran dari luar negeri sejumlah 451 kasus. Lebih lanjut, Ponorogo menempati peringkat 19 dalam hal angka perceraian 
untuk propinsi Jawa Timur.

Desa dadapan yang berada di kecamatan Balong dipilih sebagai lokasi penelitian, karena sebagian besar kasus perceraian yang terjadi berasal dari gugatan istri setelah mereka menyandang status migran kembali. Salah satu kasus yang terekam yaitu gugatan cerai dilayangkan melalui sambungan telepon. Suatu transformasi sosial yang masif, bagi perempuan yang hidup dalam lingkungan patriarkhi yang masih sangat kental. Berdasarkan temuan tersebut, studi difokuskan pada kekuasaan dalam keluarga setelah pihak istri menyandang status migran kembali, menggunakan perspektif pertukaran sosial Peter M. Blau.

Studi mengenai pekerja migran telah banyak dilakukan khususnya mengenai transformasi yang terjadi dalam keluarga. Penelitian Sri Kuntari (2015) dengan judul Menakar Perubahan Sosial Keluarga Migran menemukan keputusan perempuan menjadi pekerja migran berimplikasi pada kehidupan yang lebih baik melalui remitansi. Akan tetapi disisi lain, imbas dari perempuan menjadi pekerja migran adalah adanya kekacauan fungsi keluarga (suami atau istri).

Berbeda dari Kuntari, Pinky Saptandari (2017) menilik kajian pekerja migran perempuan dari sisi hak dan kewajiban pada keluarga dalam penelitiannya yang berjudul "Dilema Perempuan Buruh Migran dalam pemenuhan Hak dan Kewajiban pada Keluarga". Hasil studi menemukan bahwa kehidupan buruh migran perempuan berada dalam posisi yang dilematis, menanggung keluarga dan kerelaan berkorban bagi keluarga meskipun dengan berbagai resiko yang ada.

Sementara hasil penelitian yang dilakukan oleh Putri Asih Sulistiyo dan Ekawati Sri Wahyuni (2017) berjudul "Dampak Remitan Ekonomi terhadap Posisi Sosial Buruh Migran Perempuan dalam Rumah Tangga" menemukan remitan yang diberikan oleh buruh migran perempuan berkontribusi positif terhadap kondisi ekonomi keluarga. Secara nyata kondisi ini dapat dilihat dari pengambilan keputusan produktif, akan tetapi tidak terjadi pada keputusan reproduktif.

Studi kali ini berbeda karena memfokuskan pada kekuasaan dalam rumah tangga setelah istri berstatus sebagai pekerja migran. Disamping itu, pekerjaan perempuan sebelum memutuskan untuk bermigrasi juga turut diperhatikan- determinan yang terkadang kurang begitu mendapatkan perhatian mendalam pada studi terdahulu.

\section{METODE}

Metode yang digunakan dalam studi ini adalah metode kualitatif deskriptif dengan paradigma perilaku sosial. Metode kualitatif digunakan karena metode ini dapat memberikan rincian yang kompleks mengenai fenomena yang sulit diungkapkan oleh metode kuantitatif (Strauss \& Corbin, 2017: 5). Pasolong (2016: 32) menyatakan fenomena sosial, budaya, dan tingkah laku manusia tidak cukup dengan merekam hal-hal yang tampak secara nyata, melainkan juga harus mencermati secara keseluruhan dalam totalitas konteksnya. Sementara penggunaan paradigma perilaku sosial tak lepas dari konteks perubahan tingkah laku individu sebagai implikasi adanya perubahan lingkungan, dalam tataran ini, adalah migrasi perempuan sebagai pekerja migran.

Penelitian mengambil tempat di Desa Dadapan, kecamatan Balong, Kabupaten Ponorogo, yang mana ditentukan secara purposive. Subyek dalam studi ini adalah PMI kembali (PMI yang pernah bekerja di luar negeri), yang didapatkan dengan teknik snowball. Data dalam studi ini diperoleh dari wawancara mendalam (in-depth interview) dan kajian literatur yang berkaitan dengan permasalahan yang dikaji, yaitu perubahanperubahan yang terjadi dalam keluarga migran. Data yang terkumpul kemudian direduksi dan 
dianalisis dengan berpijak pada teori pertukaran sosial Blau.

\section{HASIL DAN PEMBAHASAN GAMBARAN LOKASI PENELITIAN}

Desa Dadapan merupakan salah satu desa yang terletak di kecamatan Balong, Ponorogo dengan waktu tempuh $1 / 4$ jam dari kecamatan terdekat dan $1 / 2$ jam dari kota. Bagian utara, selatan, barat dan timur desa diapit oleh kecamatan Balong dan Slahung. Sebagian besar wilayah desa yaitu 78,15\% (166,5 Ha) dari 213,06 Ha dimanfaatkan untuk pertanian.

Migrasi penduduk desa untuk menjadi pekerja migran diawali pada tahun 1983, dengan keberangkatan 4 penduduk desa yang kesemuanya perempuan. Pada awalnya, negara yang menjadi tujuan pekerja migran adalah Arab Saudi. Keberhasilan para pioneer memantik para warga lain untuk mengikuti jejak mereka. Perempuan mendominasi migrasi dengan Arab Saudi sebagai negara tujuan dan profesi yang mereka geluti adalah pembantu rumah tangga, sementara laki-laki memilih Malaysia sebagai negara tujuan.

Seiring waktu, kecenderungan tersebut mengalami perubahan, tidak hanya dari sisi negara tujuan tetapi juga dari profesi yang digeluti. Malaysia, Singapura, Hongkong dan Taiwan menjadi tujuan negara baru para pekerja migran desa Dadapan, dengan jenis pekerjaan yang tak lagi berkutat di sektor rumah tangga, tetapi telah merambah ke sektor industri dengan menjadi buruh pabrik. Salah satu yang tidak berubah, migrasi internasional di desa Dadapan masih didominasi oleh perempuan.

Keberadaan para pekerja migran secara tak langsung turut meningkatkan taraf hidup perekonomian masyarakat, yang diperlihatkan dari kepemilikan barang-barang konsumsi maupun produksi seperti rumah, kendaraan bermotor maupun sawah. Disamping itu penetrasi budaya yang terjadi pada pekerja migran diperlihatkan dari gaya hidup maupun bahasa yang digunakan. Dibalik kesuksesan, kehidupan pekerja migran menyimpan kisah kelam, yaitu perceraian, dimana sebagian besar gugatan perceraian dilayangkan oleh pihak perempuan.

\section{POSISI PEREMPUAN PRA MIGRASI}

Posisi perempuan pra migrasi merupakan determinan untuk melakukan analisis terhadap kekuasaan dalam keluarga pasca perempuan berstatus sebagai migran kembali. Signifikansi ini tak lepas dari sumbangsih yang diberikan perempuan dalam interaksinya dengan suami, tak hanya dari segi finansial akan tetapi juga dari sisi pengetahuan. Sejalan dengan premis awal Blau (dalam Scott dan Calhoun, 2004), menyatakan bahwa interaksi sosial bernilai bagi individu yang memasuki semua interaksi sosial untuk alasan yang sejalan dengan keterlibatan mereka dalam transaksi ekonomi. Individu, pada tataran ini, memerlukan sesuatu dari individu lain.

Disamping itu, kondisi pra migrasi juga turut mengungkap basis ekonomi perempuan yang pada akhirnya turut menentukan posisi tawar mereka dalam pertukaran sosial dengan suami, timbal balik ataukah sebaliknya. Selaras yang dinyatakan Zeitlin (1995), dalam pertukaran sosial, semua individu tidak mendapatkan keuntungan yang sama. Narasi mengenai posisi perempuan pra migrasi terekam dari kisah ibu Maemunah (bukan nama sebenarnya). Jauh sebelum menikah, ia telah merantau ke Jakarta dan bekerja sebagai buruh di sebuah pabrik konveksi selama 7 tahun. Perempuan asal Pemalang ini melakoni pekerjaan tersebut didasari oleh keinginannya untuk dapat membantu orang tua dan menyekolahkan adik-adiknya. Anak keempat dari tujuh bersaudara ini juga 
bertemu dengan laki-laki yang menjadi suaminya kini, pak Misiran (bukan nama sebenarnya), di Jakarta. Ia menuturkan pendapatan yang diterima selama bekerja di pabrik konveksi kala itu sebesar 450 ribu rupiah dan akan dipotong jika ia tidak masuk bekerja. Kontras dengan kondisi suaminya, sebelum menikah, pak Misiran tidak bekerja. Selama berada di Jakarta, pekerjaan yang dilakoni suaminya serabutan dan lebih banyak berada di sektor konstruksi. Pekerjaan tersebut, ia menambahkan, hanya berlangsung selama dua hari sementara seminggu kemudian menganggur. Segala urusan rumah tangga selama berada di Jakarta, dituturkan ibu Maemunah diatur oleh suami, sementara ia hanya bekerja sembari mengurus rumah. Kepulangannya dan suami dilakukan menjelang kelahiran anak pertamanya. Setelah lahiran, ia kembali ke perantauan sementara suami berada di rumah mengasuh anak. Penghasilan yang diterima, setiap bulan dikirimkan pada suami untuk membiayai keperluan anak. Keputusan menjadi pekerja migran Indonesia di Korea diambil kala ia berusia 27 tahun dan berada di sana cukup lama, yaitu selama 9 tahun, dimana 3 tahun pertama dihabiskannnya sebagai PMI illegal. Keberangkatannya sebagai PMI dilihatnya sebagai bentuk bakti terhadap keluarga dan masa depan anak.

Perjalanan yang dilalui ibu Sri (bukan nama sebenarnya) sebaliknya terekam sangat berbeda. Melepaskan masa lajang pada usia yang masih sangat belia dan tidak pernah bekerja sebelumnya, ia sangat bergantung secara ekonomi pada suami. Pengaturan rumah tangga berada di tangannya, karena suaminya Pak Tukiran seringkali merantau, yaitu ke Riau dan Malaysia. Sebelum memutuskan merantau sebagai pekerja migran di Malaysia, ia pernah bekerja sebagai babysitter (pengasuh bayi) dan merantau hingga Madura. Pekerjaan ini dilakoni karena keterbatasan ekonomi serta demi anak dan keluarga. Upah yang ia terima dikirimkan ke desa. Di dalam rumah tangga, semua keputusan berada di tangan ibu Sri. Suaminya pun tidak melayangkan protes akan hal ini atau "menyerah", karena ketidakmampuannya dalam mengatur finansial keluarga, berdasarkan penuturannya. Meskipun penentuan keputusan akhir berada di tangan istri, usul suami masih mendapatkan perhatian.

Senada dengan ibu Sri, ibu Lastri (bukan nama sebenarnya) memiliki perjalanan hidup yang hampir sama. Sebelum memutuskan untuk menjadi pekerja migran Indonesia, ia hanyalah ibu rumah tangga biasa. Ia hanya berjualan dengan hasil tak tentu ketika kebun miliknya panen. Suaminya, pak Kadimin (bukan nama sebenarnya), seringkali merantau baik sebelum maupun setelah menikah. Pendapatan yang diterima suaminya selama di perantauan, tidak dikirimkan padanya, akan tetapi diberikan langsung setiap 2 atau 3 bulan ketika kembali ke desa. Ia menambahkan ketika anak sulungnya baru berusia 2 tahun, sang suami pernah merantau ke Malaysia berstatus sebagai pekerja migran illegal. Dengan posisinya di dalam rumah tangga, suaminya menjadi penentu keputusan akhir.

Sebaliknya ibu Siti (bukan nama sebenarnya) telah terbiasa bekerja jauh sebelum ia memutuskan untuk menikah, yaitu sebagai pedagang sayur dan ayam. Ini berkat hasil didikan orang tua yang menyuruhnya untuk bekerja, dimulai dari manjaga adik-adiknya ketika kedua orang tuanya bekerja. Ketika pekerjaan rumah belum terselesaikan, ia tidak akan pergi sekolah. Kemampuan berdagang diperolehnya dari sang ibu, dimana kemampuan inilah yang diterapkan setelah berumah tangga, meskipun hasil yang didapat tidak menentu. Suaminya, pak Poniman (bukan nama sebenarnya), kini tak lagi bekerja dikarenakan faktor usia. Dalam kehidupan rumah tangga, ibu Siti menjadi penentu keputusan akhir, meskipun keputusan tersebut melalui proses diskusi dan suami tidak melayangkan protes akan hal ini.

Kisah perempuan pekerja migran yang dituturkan 
oleh keempat informan menunjukkan posisi yang berbeda dalam keluarga. Bagi perempuan pekerja migran yang memiliki basis ekonomi (pekerjaan) sebelum migrasi, penentuan keputusan akhir rumah tangga condong ke istri. Salah satu informan menunjukkan hal sebaliknya, meskipun bekerja dan memiliki posisi tawar dalam rumah tangga, pengambilan keputusan berada di tangan suami. Sementara, pekerja migran dengan kondisi pra migrasi hanya mengurus rumah tangga, pengambil keputusan akhir adalah suami.

\section{PEREMPUAN MIGRAN DAN KEKUASAAN PASCA MIGRASI DALAM KELUARGA}

Kajian mengenai kekuasaan dan posisi perempuan dalam keluarga tak dapat dilepaskan dari lingkup budaya dimana perempuan itu tinggal. Budaya Jawa telah mengakar dalam kehidupan para perempuan migran. Menilik sistem kekuasaan, keluarga Jawa menganut sistem kekuasaan bersifat dwitunggal, artinya baik ayah dan ibu memegang kekuasaan, akan tetapi keputusan akhir tetaplah berada di pihak ayah (Astiyanto, 2006). Disamping itu, sikap feodalistik yang telah mengakar dalam keluarga Jawa, seperti yang dituturkan Haq (2011), kedudukan suami lebih tinggi dibandingkan dengan istri, sebagai seorang pemimpin dengan kedudukan tinggi. Lanjut Haq dalam masyarakat Jawa, ada etika relasi suami istri yang harus dijaga, dapat ditemui salah satunya dalam serat Darmo Warsito tentang sikap istri. Ada lima sifat yang harus dimiliki istri, yaitu nurut, condhong, rumeksa, nastiti dan nyimpen wadi. Lapangan menunjukkan kondisi tersebut dengan yang terekam dari ibu Maemunah berikut:

"Ya sebetulnya yang baik ya begitu yang nurut suami. Saya yang nurut suami. Ya tetap sebagai istri kita bareng-bareng. Bantu kerja buat keluarga. Kita mikirnya begitu aja."

Pengambilan keputusan merupakan cara untuk melihat kekuasaan dalam keluarga. Ada lima tingkatan rumah tangga berdasar dari jenis keputusan yaitu dominasi suami hingga dominasi istri (Andriati dalam Suyanto \& Hendrarso (ed), 1996). Senada dengan Neuman \& Grauerholz (2002), menyatakan distribusi kekuasaan dalam keluarga dilihat dari pihak yang memutuskan keputusan yang akan dibuat, alih-alih banyaknya keputusan yang dibuat. Atau dengan kata lain, seperti dinyatakan Soputan (2007), identifikasi kekuasaan ditilik dari siapa yang memiliki, memutuskan dan mendominasi diantara kategori tersebut.

Kekuasaan menjadi dimensi utama dalam pertukaran sosial Blau. Pertukaran antara suami dan istri dari kacamata Blau, bukanlah pertukaran yang imbang dengan kata lain timpang, dimana salah satu pihak memiliki sumber daya guna mendominasi pihak lain. Pada tataran ini, Blau membatasi konsep pertukaran pada tindakat yang menimbulkan pemberian hadiah baik secara ekstrinsik (uang) maupun alternatif (rasa hormat dan kasih sayang) dari individu lain - hal yang terhenti seketika manakala reaksi yang diharapkan tidak muncul. Ketimpangan kekuasaan pada konteks ini timbul dari pertukatan dimana pihak pertama tunduk pada pihak kedua yang memiliki sumber yang dibutuhkan, sementara di sisi lain, ia tidak memiliki alternatif. Akibatnya hubungan yang terbentuk menurut Blau, bukanlah pertukaran imbal balik. Differensiasi kekuasaan, pada hal ini, adalah keluaran dari sumber daya yang elusif, kata lainnya hasil kepemilikan barang-barang langka. Kondisi powerless dialami oleh pihak yang tidak memiliki sumber daya untuk dipertukarkan.

Dalam sudut pandang teoritisi pertukaran sosial, menurut Newman \& Grauerholz (2002), faktor kunci differensiasi kekuasaan di keluarga adalah dependensi. Dependensi dan kekuasaan berkorelasi satu sama lain - semakin tergantung 
individu pada individu lain, semakin berkurang kekuasaan individu tersebut. Basis ekonomi menurut Bashin (1984) merupakan kekuatan laki-laki untuk mengekang dan mengontrol perempuan, ditambah dengan sistem patriarki yang berkembang dalam masyarakat.

Kondisi perempuan pra migrasi menunjukkan derajat dependensi yang beragam. Bagi pekerja migran perempuan dengan basis ekonomi, derajat dependensi terhadap laki-laki tidak begitu kuat, bahkan dapat dikatakan posisi mereka setara. Sebaliknya pekerja migran perempuan tanpa basis ekonomi, menunjukkan derajat dependensi yang tinggi.

Seiring dengan meningkatnya basis ekonomi pasca migrasi, tingkat ketergantungan perempuan terhadap laki-laki dalam rumah tangga berkurang. Ekonomi, seperti yang diutarakan Bashin (1984), sebagai sumber daya yang dipertukarkan dalam rumah tangga guna mengontrol perempuan, tidak lagi didominasi oleh laki-laki. Kondisi lapangan menunjukkan hal tersebut yang dirangkum dalam tabel berikut :

\begin{tabular}{|c|c|l|}
\hline \multicolumn{3}{|c|}{ Tabel 1.1 : Kondisi Pasca Migrasi } \\
\begin{tabular}{|c|c|c|}
\hline Kondisi Perempuan & Pra Migrasi & \multicolumn{1}{|c|}{ Pasca Migrasi } \\
\hline Bekerja & Dependensi rendah & $\begin{array}{l}\text { Dependensi rendah, posisi } \\
\text { dalam rumah tangga semakin } \\
\text { kuat }\end{array}$ \\
\hline Tidak Bekerja & Dependensi tinggi & $\begin{array}{l}\text { Dependensi melemah, posisi } \\
\text { dalam rumah tangga semakin } \\
\text { meningkat }\end{array}$ \\
\hline
\end{tabular} \\
\hline
\end{tabular}

Tabel menunjukkan kondisi pasca migrasi yang berbeda. Pada perempuan migran dengan basis ekonomi pra migrasi, posisi mereka diperkuat dengan migrasi yang dilakukan. Pada kasus ibu Sri, posisi pra migrasi dalam keluarga telah kuat, dikarenakan kondisi suami yang seringkali merantau dan bertambah kuat setelah ia bekerja. Kondisi serupa ditunjukkan oleh ibu Siti. Pada tataran ini, pertukaran sosial yang terjadi pada kedua keluarga informan tersebut, dikatakan setara, karena pihak suami maupun istri turut menyumbang finansial keluarga.

Ekonomi menjadi sumber daya utama istri dalam pertukarannya dengan suami, pada keluarga dimana suami lebih banyak menganggur, seperti yang terekam pada keluarga ibu Maemunah. Dependensi suami pada istri cukup tinggi. Menukil pokok pemikiran teori pertukaran sosial, pihak suami tidak menemukan alternatif lain sehingga membutuhkan sumber daya yang dimiliki pihak istri. Sehingga alternatif yang tersedia, suami berada pada posisi dependen daripada istri, yang terlihat dari pengambilan keputusan akhir dalam rumah tangga. Adapun relasi yang terbentuk bersifat timpang, yang berimplikasi pada posisi tawar perempuan dalam keluarga.

Pada pekerja migran dengan kondisi pra migrasi tanpa basis ekonomi atau tidak bekerja, menunjukkan derajat dependensi yang tinggi, dimana keputusan akhir keluarga berada di tangan suami, seperti yang terekam pada Ibu Lastri. Ekonomi disini menjadi sumber daya langka yang menentukan differensiasi kekuasaan dalam keluarga. Sementara, kondisi pasca migrasi pada keluarga ibu Lastri menunjukkan hal yang sebaliknya.

\section{DEKONSTRUKSI KEKUASAAN DALAM KELUARGA PEKERJA MIGRAN PEREMPUAN}

Mengacu pemikiran Blau tentang pertukaran sosial, kondisi pasca migrasi menunjukkan bahwa ekonomi tidaklah menjadi sumber daya langka tak tergantikan tanpa adanya alternatif lain. Ekonomi istri menjadi alternatif dari sumber daya tersebut yang semata-mata hanya dimiliki oleh laki-laki. Migrasi telah merubah wajah kekuasaan dalam keluarga, seiring dengan meningkatnya kondisi finansial istri pasca migrasi yang turut 
mengekskalasi posisi tawar mereka dalam rumah tangga, khususnya dalam pengambilan keputusan. Kekuasaan laki-laki dengan ekonomi yang dipertukarkan dalam rumah tangga perlahan memudar dengan tak lagi menjadi sumber daya langka pada pertukaran dengan istri.

Signifikansi kemampuan finansial perempuan pekerja migran terhadap peningkatan posisi tawar, ditandai dengan perempuan yang cenderung mendominasi dalam keputusan akhir keluarga pra migrasi keputusan akhir berada di pihak laki-laki karena posisi perempuan tidak bekerja. Hal ini terekam dalam kehidupan ibu Lastri. Posisi tawar perempuan yang mengalami peningkatan, semata-mata tidak hanya disebabkan oleh kemampuan finansial mereka sebagai pekerja migran. Basis ekonomi pra migrasi turut memberikan andil dalam signifikansi posisi tawar perempuan dalam rumah tangga. Posisi ini makin diperkuat oleh kemampuan finansial mereka sebagai pekerja migran.

Temuan ini selasar dengan hasil kajian Triana Sofiani dalam jurnal penelitian volume 6 no 2, peralihan basis ekonomi ke tangan istri memberikan kekuatan bagi istri dalam meruntuhkan struktur kerja yang dominan dan mendiskriminasi perempuan karena struktur patriarkhis yang ada pada masyarakat. Disamping itu, pergeseran relasi yang terjadi berubah dari vertikal patriarkhi menjadi horizontal relationship ke vertikal matriarkhis, dengan sifat revolutif dan evolutif/dynamic equilibrium. Nainggolan Togiaratua (2008) dalam kajiannya menemukan hal yang serupa, pergeseran pola relasi gender lokal terjadi pasca migrasi, dari sifatnya yang feminim menuju Androgini.

Kontras dengan temuan kajian yang dilakukan Hendrarso (2008) terhadap perempuan pengrajin tempe di Surabaya, dimana penguasaan basis ekonomi, tidak semerta-merta menambah "kekuasaan" perempuan dalam relasi dengan laki-laki. Sebaliknya mereka justru "tereksploitasi”, karena beban kerja membuat tempe membebani mereka hampir tanpa bantuan suami. Laki-laki memiliki kekuasaan yang lebih pada segala bidang. Hampir sama dengan yang dinyatakan Hendrarso, Saptandari (2017) dalam jurnal Respons volume 22 no 02 , menulis buruh migran walaupun dipotret sebagai pahlawan yang menyelamatkan ekonomi keluarga dan disibukkan dengan berbagai urusan, perempuan tetap berbalut dengan peran stereotipe yang disematkan pada mereka, yaitu ibu rumah tangga yang baik, sabar dan harus siap berkorban bagi keluarga.

Dekonstruksi kekuasaan laki-laki dalam rumah tangga, terlihat dari keputusan akhir yang didominasi oleh pihak perempuan, utamanya ekonomi. Sejalan dengan pernyataan Goode (2007), dominasi perempuan meningkat pada tataran putusan ekonomi yang krusial. Pengambilan keputusan oleh pihak istri telah masuk ke semua lini kehidupan rumah tangga. Pemisahan pengambilan keputusan antara bidang publik dan bidang privat semakin mengabur, menyisakan sedikit ruang keterlibatan suami dalam pengambilan keputusan. Dominasi perempuan menguat karena timpangnya basis ekonomi suami dengan basis ekonomi istri. Salah satunya terlihat dalam pengambilan keputusan penting yang menunggu persetujuan pihak istri. Hal ini terekam pada keluarga ibu Lastri pada pembelian hewan ternak dan sawah. Pihak laki-laki ingin membeli sapi yang diutarakan pada sang istri. Akan tetapi ditolak dengan alasan kesehatan suami yang tidak begitu baik. Mendapat penolakan dari istri, pihak laki-laki hanya bisa menerima keputusan tersebut tanpa adanya protes. Berikut kutipan wawancara dengan ibu Lastri berkaitan dengan hal tersebut.
“....... itu waktu mau beli sapi. Saya ndak setuju. Ndak. Aku nggak setuju kan kasihan dia. Dia sakit-sakitan gitu. Kecapekan. Itu sapi kan butuh perawatan. Kan dia sudah sakit jantung gitu. Jadi saya kan jaga-jaga, 
kasihan. Ya udah ndak setuju ya udah."

Dominasi istri terhadap keputusan ekonomi rumah tangga, masih menyisakan ruang bagi laki-laki untuk terlibat di dalamnya. Bahkan pada dua keluarga informan, laki-laki masih memegang keputusan akhir dalam bidang ekonomi. Pada keluarga ibu Lastri, keputusan laki-laki tersebut nampak pada pembelian perabot rumah. Meskipun demikian, ia menuturkan tetap diberitahu akan hal tersebut, karena biaya yang digunakan berasal dari istri. Sementara pada ibu Sri, kendali penuh laki-laki terletak pada pembelian hewan ternak, dimana pembelian berasal dari kerja suami. Pada kasus ini, suami masih memiliki ruang dalam keputusan keluarga karena basis ekonominya. Sama halnya dengan pemberian bantuan pada orang tua. Pemberian bantuan terhadap orang tua dilakukan melalui proses diskusi dengan suami, meskipun finalisasi tetap berada di tangan perempuan. Ia menuturkan tidak pernah dilarang oleh suaminya dalam memberikan bantuan kepada orang tuanya yang tinggal dalam satu rumah. Begitu pula dengan suami yang mengajaknya berdiskusi ketika akan memberikan bantuan terhadap orang tua. Berikut kutipan wawancara dengan ibu Sri.

" Ya kalau orang tuaku memang sudah ikut aku. Jadi urusan orang tuaku tinggal ak semua. Bapak itu mendukung. Pasti ijin kalau kasih apa-apa. Gimana kalau aku kasih. Bilangnya gitu ya ndak papa."

Sejalan dengan yang terjadi dalam keluarga ibu Siti, dimana dalam hal pemberian kepada orang tua juga melalui proses yang sama, melibatkan kedua belah pihak, baik istri maupun suami.

Dominasi istri yang kuat dalam rumah tangga kontras dengan temuan penelitian Putri Asih Sulistiyo dan Ekawati Sri Wahyuni dalam Jurnal Sodality volume 6 no 03, dimana suami relatif mendominasi distribusi kekuasaan dalam rumah tangga, misalnya penggunaan remitan, penentuan jumlah remitan yang dikirim dan jenis pekerjaan secara spesifik. Sementara pihak perempuan memiliki bagian tersendiri, otonomi tersebut nampak dari keputusan untuk bekerja di luar negeri. Beberapa keputusan diambil secara bersama dan relatif tidak ada dominasi salah satu pihak khususnya pengambilan keputusan di bidang produktif.

Migrasi perempuan dengan peningkatan basis ekonomi, mendekonstruksi kekuasaan laki-laki dalam keluarga, dengan keputusan akhir didominasi oleh pihak istri. Sehingga dapat disimpulkan, dekonstruksi kekuasaan laki-laki dalam keluarga disebabkan oleh basis ekonomi yang memberikan istri ruang untuk meningkatkan posisi tawar dalam pengambilan keputusan keluarga.

Dekonstruksi kekuasaan dalam keluarga migran, tidak hanya disebabkan oleh peningkatan basis ekonomi perempuan semata. Pengetahuan maupun ide-ide yang diperoleh perempuan selama merantau turut pula mempengaruhi. Mencuplik teori pertukaran sosial, barang yang dipertukarkan bersifat instrinsik (cinta, kasih sayang, rasa hormat, dll) maupun ekstrinsik (uang dan tenaga fisik). Pengetahuan perempuan adalah barang pertukaran yang sifatnya instrinsik. Pengetahuan yang mendekonstruksi kekuasaan dalam bentuk keputusan akhir terekam pada keluarga ibu Siti. Di dalam keluarga, anak mendapatkan porsi lebih dalam pengambilan keputusan akhir keluarga dibanding suami. Bahkan pada tataran ini, suami tidak dilibatkan sama sekali. Dengan pengalamannya selama merantau, pengalaman yang didapatkan lebih banyak. Berbeda dengan suami, meminjam istilah ibu Siti, yang hanya orang rumahan tanpa pengetahuan akan dunia luar. Kehidupannya hanya berputar pada sawah dan rumah. Oleh karena hal tersebut, suaminya tidak pernah mengambil keputusan sendiri. Sehingga, ia selalu berdiskusi bersama anak dalam penentuan keputusan akhir. 
Kondisi tersebut dapat dilihat dari wawancara berikut.

"Ndak pernah mutuskan harus ini harus ini.

Orang medengan seperti itu. Nggak menghina tapi itu ya ndak kemana-mana. Ndak pernah pergi. Apa itu orang di rumah aja. Cuma kerja di sawah. Masuk. Minum. Makan.

Ndak keluar di jalan. Pengalamannya itu masih kurang."

Dekonstruksi kekuasaan dalam keluarga hanyalah secuil implikasi dari adanya migrasi pekerja migran perempuan, dengan ekonomi sebagai determinan utamanya dan pengetahuan sebagai determinan minor. Peningkatan kondisi finansial perempuan beriringan dengan posisi tawar terhadap suami, yang pada akhirnya berimplikasi pada penentuan keputusan akhir dalam keluarga. Kuatnya dominasi perempuan ini menggambarkan seolaholah laki-laki kehilangan kekuasaannya dalam rumah tangga, meminjam istilah dari Susan Rogers, sebagai "mitos dari dominasi laki-laki”. Pepatah jawa yang mengatakan "swargo nunut neroko katut" yang disematkan pada perempuan tampaknya perlahan mulai memudar.

\section{KESIMPULAN}

Migrasi pekerja migran perempuan memberikan implikasi yang cukup signifikan terhadap perubahan yang terjadi di dalam keluarga. Peningkatan basis ekonomi beriringan dengan peningkatan posisi tawar perempuan terhadap laki-laki yang pada akhirnya memberikan "kekuasaan" pada perempuan untuk mendominasi putusan akhir dalam rumah tangga. Determinan lain yang berpengaruh adalah tingkat pengetahuan. Pengetahuan yang diperoleh perempuan selama berada di perantauan memberikan mereka kemampuan baru dalam bertindak dan memutuskan. Kuatnya posisi tawar perempuan mendekonstruksi kekuasaan laki-laki dalam rumah tangga.

\section{DAFTAR PUSTAKA}

Astiyanto, Heniy. 2006. Filsafat Jawa : Menggali Butir-Butir Kearifan Lokal. Yogyakarta: Warta Pustaka

Bhasin, Kamla, 1984. Menggugat Patriarkhi : Pengantar tentang Persoalan Dominasi terhadap Kaum Perempuan. Yogyakarta: Yayasan Bentang Budaya

Febrihapsari, Mahardani. 2011. Relasi Gender dalam Keluarga Migran TKW (Studi tentang Pergeseran Relasi Kekuasaan Suami-Istri Pasca Migrasi). Tesis. Surabaya: Universitas Airlangga

Goode, William J. 2007. Sosiologi Keluarga. Jakarta : PT Bumi Aksara

Haq, Muhammad Zaairul. 2011. Mutiara Hidup Manusia Jawa : Menggali Butir-Butir Ajaran Lokal Jawa untuk Menuju Kearifan Hidup Dunia dan Akhirat. Malang: Aditya Media Publishing

Hendrarso, Emy Susanti. 2008. Ketimpangan Gender dan Ketidakberdayaan Perempuan Miskin Perkotaan. Surabaya : Insan Cendekia Newman, David M, \& Liz Grauerholz, 2002. Sociology of Families Second Edition. California : Pine Forge Press

Pasolong, Harbani. 2016. Metode Penelitian Administrasi Publik. Bandung : Penerbit Alfabeta

Saptandari, Pinky. "Dilema Perempuan Buruh Migran dalam Pemenuhan Hak \& Kewajiban pada Keluarga”, Jurnal Respons volume 22 no 02 Tahun 2017

Scott, W. Richard, \& Calhoun, Craig. 2004. Peter Michael Blau 1918-2002 : A Biographical Memoir, Washington DC : The National 
Academy Press

Sofiani, Triana. "Pergeseran Pola Relasi Gender dan Eskalasi Cerai Gugat dalam Keluarga Perempuan Pekerja Migran”, Jurnal Penelitian volume 6 nomor 2 Tahun 2009

Strauss, Anslem. \& Corbin, Juliet. 2017. Dasar-Dasar Penelitian Kualitatif : Tata Langkah dan Teknik-Teknik Teoritisasi Data. Yogyakarta: Pustaka Pelajar

Soputan, Grace Jenny, 2007. “Aspirasi Perempuan Bekerja: Hubungan Kekuasaan Laki-laki dan Perempuan dalam Sektor Informal. Dapat diunduh di http://jurnal.pdii.lipi.go.ig/admin/jurnal/81071724.pdf

Sulistiyo, Putri Asih \& Wahyuni, Ekawati Sri.

"Dampak Remitan Ekonomi terhadap Posisi

Sosial Buruh Migran Perempuan dalam

Rumah Tangga”. Sodality: Jurnal Sosiologi

Pedesaan volume 6 No 03 Tahun 2017

Susanti, Erma. 2005. Berdaya tapi Dipinggirkan:

Wajah Perempuan dalam Ekonomi, Surabaya:

Lutfansah

Suyanto, Bagong. \& Hendrarso, Emy Susanti, 1996. Marginalisasi Menuju Pemberdayaan, Surabaya, Airlangga University Press

Togiaratua, Nainggolan. "Gender dan Keluarga Migran di Indonesia, Jurnal Penelitian dan Pengembangan Kesejahteraan Sosial

Volume 13 No 03 Tahun 2008

Kuntari, Sri. “Menakar Perubahan Sosial Keluarga Migran”, Jurnal PKS volume 14 No 2 Tahun 2015

www.kompas.com/10 negara Penampung TKI

Terbanyak, Taiwan Hampir Samai Malaysia www.cnnindonesia.com/Bank Dunia: Remitansi

TKI Tembus Rp118 Triliun.

www.surabayainside.com/Pekerja Migran Dominasi

Perceraian di Ponorogo. 